\title{
AUA 2015 Endoüroloji İzlenimleri
}

\author{
Vahit Güzelburç
}

Medipol Üniversitesi, Tıp Fakültesi, Üroloji Anabilim Dalı, İstanbul

A merikan Üroloji Derneği (AUA) yıllık kongresi New Orleans Ernest N. Morial Kongre Merkezi'nde yaklaşık 16 bin kişinin katılımıyla gerçekleşti. Kongrede "endoüroloji ve üriner sistem taş hastalığ ${ }^{\prime \prime}$ " başlığı altında 27 ülkeden 34 sözel bildiri sunumu, 14 video sunumu ve 179 poster sunumu yapıldı. Bildirilerin yarısından fazlasını ev sahibi ülke sunarken Türkiye bu oturumlarda Japonya ve Kanada'dan sonra en çok bildiri sunan 4. sıradaki ülke oldu. Endoüroloji kapsaminda 6 kurs düzenlendi. Ana salonda:

- Şok dalgalitotripsi (SWL) emekli edilmeli (çapraz ateş oturumu)

- Zorlu taş olguları (ikinci görüş oturumu)

- Perkütan nefrolitotomi (3 canlı cerrahi, 1 panel tartışması)

- Taşlarda üreteroskopi: tozlaştırma mi, basketle toplama mı? (kritik tartışma oturumu)

- Ürik asit taşlarının patofizyolojisi ve tedavisi (son gelişmeler oturumu)

- Taşların ultrasonla itilmesi (son gelişmeler oturumu) başlıklı oturumlar düzenlendi.

Kongrede verilen 6 video ödülünün 2'sini aralarında ülkemizden meslektaşlarımızın bulunduğu çalışmalar kazand1. Illk ödül kazanan video olan "Perineal Robot Yardımlı Laparoskopik Radikal Prostatektomi" başlıklı çalışmada, Oktay Akça ve Selami Albayrak çalışmaya Türkiye'den katılan araştırmacılar iken; diğer ödül Türkiye'den Remzi Sağlam, A.Sinan Kabakçı, Zafer Tokatlı ve Abdurrahim İmamoğlu'nun yer aldığı “Avicenna Roboflex ile Robot Yardımlı Fleksible Üreteroskopik Lazer Litotripsi” başlıklı çalışmaya verildi.

Amerikan Üroloji Derneği-Avrasya Üroloji Platformu Toplantısı'nın (AUA-EUP) bu yıl dördüncüsü düzenlendi. Oturum AUA 2015'in resmi bilimsel programında yer aldı. Türkiye'den çok sayıda konuşmacı ve panelistin katılımının yanı sira Stephen Y. Nakada, James E. Lingeman ve Thomas Knoll programın endoüroloji oturumlarına katılan yabancı konuşmacilar oldu.

\section{Taş Hastalığında Temel Çalışmalar}

Taş hastalığından korunmada yeni ışık olabilecek çalışmalarında Kustmarsev ve ark.'ları makrofajların böbreğin korunmasında kritik role sahip olduğunu vurgulayarak periferik kandan mononükleer hücreler ve monositleri purifiye etmişlerdir. Monositlerin makrofajlara differansiyasyonu sonrası, cerrahi olarak insandan elde edilmiş 3-5 mm çaplı kalsiyum oksalat monohidrat ve kalsiyum fosfat taşları ile temas etmeleri sağlanmış ve bu makrofajların inorganik taş kristallerini adım adım tahrip edebildiği gösterilmiştir. Böylece olgun makrofajların böbrek taşlarının sindirilmesi ve taşların böbrekten uzaklaştırılmasında önemli role sahip olabileceği rapor edilmiştir. MP33-09

Progesteronun üreterler dâhil tüm üriner sistemde relaksasyona sebep olduğunun bilindiğini vurgulayan Yürük ve ark.'ları 18-40 yaş arası 32 hastayı içeren çalışmalarında menstruel siklusun luteal fazında progesteron artışının stente bağlı semptomlarda azalmayla sonuçlandığını bildirmişlerdir. MP33-08

Chung ve ark.'ları dislipidemisi olan hastalarda statin kullanımının üst üriner sistem taş oluşumuna etkisini araştırdıkları çalışmalarına, taş hastalığı olmayan ve dislipidemi tedavisi başlanan 5926 erkek ve 5859 kadın hasta ile 23570 kişilik kontrol grubunu dahil etmişlerdir. Hasta ve kontrol gruplarının 8 yıllık toplum temelli takip çalışması sonucunda statin kullanan ve kullanmayanlar arasında taş hastalığının gelişmesinde fark olmadığını bildirmişlerdir. MP34-03

Diabetes mellitus (DM) hastalarının daha yüksek oranda nefrolitiyazise sahip olduğunu vurgulayan Fram ve ark.'larının insülin kullanımının 24 saatlik idrar parametrelerine etkisini araştırdıkları çalışmalarında taş cerrahisi uygulanan 1013 hastanin 24 saatlik idrar verileri retrospektif olarak değerlendirilmiştir. Hastalar 1-İnsülin bağımlı DM, 2-İnsülin bağımlı olmayan DM ve 3-DM olmayan böbrek taş1 hastaları olmak üzere 3 gruba ayrılmıştır. İnsülin bağımlı DM hastalarında daha düşük idrar kalsiyum, fosfat ve sitrat düzeyi saptanırken, insülin bağımlı olmayanlarda daha düşük idrar $\mathrm{pH}^{\prime} 1$ saptandığ bildirilmiştir. MP34-10

\section{Taş Hastalığı Değerlendirmesi}

Büyük çoğunluğu obstrüktif üreter taşları sebebiyle oluşan ürosepsis, \%20 mortalite oranına ulaşan üriner sistem kaynaklı ağır sistemik enfeksiyon olarak tanımlanmaktadır. Papagiannopoulos ve ark.'ları sepsis ve pozitif idrar kültürünü öngörmede prokalsitonin, beyaz küre (WBC) sayımı, eritrosit sedimentasyon hızı (ESR) ve C-reaktif protein (CRP) değerlerinin sensitivite, spesifisite, pozitif prediktif değer ve negatif prediktif değerlerini karşılaştırmıştır. Ürolitiyazis nedeniyle akut obstrüksiyon tespit edilen hastaların dahil edildiği çalışma sonucunda prokalsitonin değerinin sepsisi ve pozitif kültürü öngörmede daha spesifik olduğu bildirilmiştir. MP80-20 
Bilgisayarlı tomografi (BT) görüntülemeleri esnasında oluşan radyasyon maruziyetini değerlendiren Jepperson ve ark.'ları single enerji BT, düşük doz enerji BT ve dual source dual energy BT (DECT) cihazlarını karşılaştırmışlardır. DECT single enerjiye göre $\% 40$ daha az radyasyona maruziyet sağlarken, düşük doz $\mathrm{BT}^{\prime}$ ye göre aynı radyasyon maruziyetinde taş yapısı hakkında daha fazla bilgi verebildiği bildirilmiştir. MP75-17

Uyku postürünün böbrek taşı oluşum tarafını belirlemedeki etkisini araştıran Cheng ve ark.'ları, obstrüktif uykuapne sendromu nedeniyle polisomnografi yapılan hastaların verilerini retrospektif değerlendirilmişlerdir. Çalışmaya tek taraflı böbrek veya üreter taşı nedeniyle ESWL veya üreteroskopi uygulanmış olan 67 hasta dahil edilmiştir. Sonuçta uyku postürünün unilateral taş hastalığıyla korelasyon gösterdiği bildirilmiştir. MP80-14

Genel toplumda sık görülen 25-hidroksi D vitamini eksikliğinin tedavisinde 8 haftallk D3 vitamin takviyesi önerilmesine karşın; bu tedavinin nefrolitiyazis oluşma riskine etkisi hakkında fikir birliği olmadığını vurgulayan Park ve ark.'ları, daha önce taş hastalığı olmadığı bilinen 48.697 hastayı izlemişlerdir. D vitamini tedavisi sonrası 3 yıl süreyle takip sonucunda haftalık 50000 IU takviyenin taş

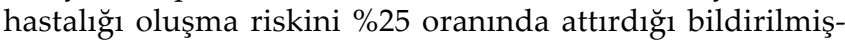
tir. PD51-08

Asemptomatik böbrek taşlarının doğal seyrini inceleyen Ghani ve ark.'ları 12 çalışmada toplam 1712 hastanın takip verilerinin değerlendirildiği metaanalizin sonuçlarını bildirmişlerdir. Asemptomatik böbrek taşlarının takibinde ağrı yıllık \%10 hastada oluşan ve en sik saptanan semptom iken; daha sonra sirasiyla hastaların \%6'sinda sık idrar hissi, \%3'ünde hematüri ve \%1'inde enfeksiyon gelişmiştir. Taşların düşmekten (\%6) çok büyüme (\%14) eğiliminde olduğu ve \%23 hastada cerrahi tedavi ihtiyacı geliştiği rapor edilmiştir. PD51-02

\section{Taş Hastalığının Medikal Tedavisi}

Bisfosfanatlar osteoporoz tedavisinde kullanılmakta ve etkili bir şekilde kemik rezorpsiyonunu engellediği bilinmektedir. Yasui ve ark.'ları osteoporoz tanılı $>70$ yaş erkek ve postmenapozal kadın hastaları değerlendirdikleri çalışmalarinda alendronat tedavisinin hizla ve belirgin olarak idrar kalsiyumunu azalttığını bildirmişlerdir. Alendronat tedavisinin sadece kemik mineral yoğunluğunu iyileştirmekle kalmayıp erkeklerde daha belirgin olmak üzere her iki cinsiyette de kalsiyum taşı oluşum riskini azalttığı, tedavi alanlarda yıllık ürolitiyazis insidansının anlamlı olarak azaldığı da bildirilmiştir. MP41-03

Semptomatik ürolitiyazisli gebelerde medikal ekpulsif terapide kullanılan tamsulosinin güvenilirliğini araştıran çalışmada Bailey ve ark.'ları kontrol grubuyla birlikte gebe hastaları postpartum 90 gün takip etmişlerdir. Fetusların tamsulosine ortanca maruziyet süresi 3 gün olarak bildirilen çalışmada, ortalama gestasyonel yaş, APGAR skoru, doğum ağırlığ sonuçta ani infant ölümü sendromuyla (SIDS) kaybedildiği bildirilmekle birlikte; eşleştirilmiş kohort karşılaştırmasında gebelikte tamsulosin kullanıminın fetal veya maternal olarak olumsuz etkilerinin bulunmadığı bildirilmiştir. MP41-05

Shabana ve ark.'ları 1 cm'den küçük üreter alt uç taşları- nın tedavisinde alfuzosin veya tamsulosinin metil prednizolon ile kombinasyonunun monoterapiden daha etkin taşsızlık sağladığını ve metil predizolona bağlı gelişebilen geçici hipergliseminin ise tedavinin durdurulmasıla sonlandığını bildirmişlerdir. MP41-09

Ayrıca. stente bağlı semptomları azaltmada tamsulosin veya solifenasin veya kombinasyon tedavisinin fayda sağlamadığını Park ve ark.'ları bildirmişlerdir. MP41-17

\section{Taş Hastalığı SWL Tedavisi}

Düşük komplikasyon oranına sahip SWL tedavisi esnasında nadiren ventriküler taşikardi gibi ciddi aritmiler görülebilmektedir. Aritmi gelişen hastaların pozisyonlarının 15-20 derece rotasyonunun etkisini araştıran Alzahrani ve ark.'ları 819 hastalık çalışmada daha zayıf, daha genç yaş grubunda ve sağ tarafta taşı bulunan hastalarda aritmi riskinin arttığını bildirmişlerdir. Aritmi gelişen toplam 20 hastanın pozisyonunun 15-20 derece düz veya oblik rotasyonu sonrasında 2 dakika dinleme ile kalbin repolarizasyonu sağlanarak hastaların \%85'inde 120/dk şok hızında SWL'ye devam edilebilirken bu manevraya rağmen aritmisi devam eden \%15 hastada kalp ritmiyle uyumlu geleneksel gated SWL uygulamasına geçilmesi gerektiği bildirilmiştir. PD13-08

\section{Taş Hastalığı Cerrahi Tedavisi}

Fleksibl üreteroskopi (fURS) ile taş tedavisinde, tozlaştırma (dusting) ile basketle toplama tekniklerinin başarısını karşılaştıran prospektif çalışmanın ön sonuçlarını bildiren Chew ve ark.'ları; operasyon süresini basketle toplama grubunda belirgin daha uzun olarak bildirirken, kullanılan enerji miktarını tozlaştırma grubunda daha yüksek bildirmişlerdir. Sonuçlarda dikkat çeken veri ise operasyondan 4-6 hafta sonra direkt üriner sistem grafisi veya ultrasonografi ile yapılan değerlendirmede tozlaştırma grubunda $\% 30.8$ oranında rezidüel fragman saptanırken bunun \%25'inin $4 \mathrm{~mm}$ 'den büyük fragmanlar olduğu; basketle toplama grubundaysa rezidüel fragman saptanma oranının sadece $\% 8.8$ olduğu ve bu fragmanların hiçbirinin $4 \mathrm{~mm}$ 'den büyük olmadığ1 vurgulanmıştır. PD13-01

Daha büyük taşlara fURS ile taş tedavisi uygulanmasının ürologlar arasında pyelovenöz ve pyelolenfatik emilimi arttırabileceği endişesi oluşturduğunu vurgulayan Güzelburç ve ark.'ları fURS'nin renal hemodinami üzerine etkilerini Doppler ultrasonografi ile preoperatif, peroperatif ve postoperatif değerlendirdikleri çalışmanın ön sonuçlarında; hastaların renal arter ve periferik dallarında peak sistolik velosite, end diastolik velosite ve rezistif indeks değerlerinde anlamlı değişiklik olmadığını ve uzayan operasyon sürelerine rağmen fURS'nin güvenli bir teknik olduğunu bildirmişlerdir. MP28-16

Büyük üst üreter taşlarında fURS ile laparoskopik üreterolitotomi tekniklerini karşılaştıran Tuğcu ve ark.'ları 103 hastayı retrospektif olarak değerlendirmiş. fURS ile daha kısa hastane yatışı, daha az analjezik kullanım ihtiyacı olurken laparoskopik üreterolitotomi hastalarında daha kısa operasyon sürelerinde, tek seansta, daha yüksek oranda taşsızlık ve daha az ek girişim ihtiyacı olduğunu bildirmişlerdir. MP38-07

İki cm'den küçük böbrek taşları tedavisinde fURS ve mini 
PNL tekniklerinin sonuçlarını karşılaştıran Akbulut ve ark.'ları başarı oranlarını benzer olarak bildirmekle birlikte; fURS grubunda ateş yükselmesi, mini PNL grubunda ise genel anestezi altında double-J kateter yerleştirilme ihtiyac1nın daha sık görüldüğünü ifade etmişlerdir. Sonuç olarak daha kısa floroskopi kullanımı ve kısa hastanede yatış süresi nedeniyle fURS tekniğinin daha avantajlı olduğu bildirilmiştir. MP28-20.

PNL sonrası sonuçları öngörmede kullanılan skorlama sistemlerini karşılaştıran Tailly ve ark.'ları Guy's, S.T.O.N.E ve CROES nomogramlarını karşılaştırmışlardır. Taşsızlık oranını en iyi S.T.O.N.E skorlaması gösterirken, Guy's nomogramının daha uzun hastanede kalışı göstermede yardımcı olduğu gösterilmiştir. S.T.O.N.E ve CROES’un daha uzun operasyon süresini gösteren güçlü belirteçler olduğu bildirilirken; hiçbir skorlama sisteminin postoperatif komplikasyonları öngöremediği vurgulanmıştır. PD51-01.

PNL sonrası postoperatif major komplikasyonların değerlendirildiği ve 2.380 hastanın dahil edildiği prospektif çalışmada Posada ve ark.'ları yaş, komorbidite sayısı ve üst pole aksesin major komplikasyonlarla anlamlı ilişkisini saptarken; geçirilmiş üriner enfeksiyon öyküsü, geçirilmiş PNL öyküsü, vücut kitle indeksi, multipl trakt kullanımının major komplikasyonlarla ilişkili olmadığını bildirmişlerdir. MP30-20

\section{Pediatrik Endoüroloji}

Çocuk yaş grubunda astım ve ürolitiyazis ilişkisini değerlendiren 865 çocuk hastanın dâhil edildiği çalışmada Kartha ve ark.'ları pediatrik astım hastalarında nefrolitiyazis prevalansını yaklaşık 3 kat daha fazla saptarken tam tersi bakış açısıyla, taş hastalığı olan çocuklarda 5 kat daha sık astım görüldüğü ve 12 yaş altı taş hastası 3 çocuktan 1'inde astım saptandığını bildirmişlerdir. PD51-09

Pediatrik böbrek taşı hastalarında mikro PNL ile mini PNL tekniklerini karşılaştıran Karatag ve ark.'ları küçük böbrek taşlarında kan kaybı, komplikasyon oranı ve taşsızlık oranları arasında anlamlı fark saptanmadığını bildirmişlerdir. PD13-09

\section{Teknoloji ve Cihazlar: Cerrahi Eğitim ve Beceri Değerlendirmesi}

fURS eğitimi için Marroig ve ark.'ları taze insan kadavraS1 toplayıcı sistemine enjekte edilen sarı renkte reçine ile 10 farklı silikon model oluşturarak; özellikle eğitim alanların zor akses sağlayabildiği alt poldeki minör kaliksler, keskin açlanma yapan veya perpendiküler seyreden minör kaliksler, uzun infindibulum gibi değişik anatomik varyasyonlarda, kalikslerin farklı renklendirilmesi ile oryantasyonu kolaylaştıran eğitim modeli oluşturmuşlardır. MP28-07

Robotik anatrofik nefrolitotomi faz 0 çalışmasını Sood ve ark.'ları domuz modelinde gerçekleştirmişlerdir. Renal arter posterior segmentinin klempe edilmesini takiben anatrofik planın Near infrared fluorescence (NIRF) kullanılarak belirlenebilmesi için IV indocyanin green verilmiştir. Hilar damarların klemplenmesi sonrası konsol süresi 114 dk, sıcak iskemi süresi $36 \mathrm{dk}$. ve soğuk iskemi süresi $33 \mathrm{dk}$. olarak bildirilmiştir. PD13-03

Bunların yanında, farklı merkezler tarafından 4 poster oturumu ve 1 video oturumunda sunulan hasta Bilgisayarlı Tomografi görüntülerine göre 3D yazıcıda üretilmiş böbrek tümörü modelleri tanıtıldı. Konuşmacılar günümüzde ameliyatı 'bir defa izle, bir defa yap, bir defa yaptır' eğitim modelinin yerine "ameliyatı önce çok defa simüle et, sonra yap" eğitim modeline geçilmesi gerektiğini öne sürdüler. DICOM'dan alınan hastaya ait böbrek görüntülerinin vasküler yapılar, toplayıcı sistem, kitle, parankim ve tümör özellikleri, polivinil alkol hidrojel ile 3D yazıcılarda farklı renklerde modellenerek yüzey, içerik, kurgusal geçerliliği sağlanmıştır. Hastaya cerrahi öncesi model üzerinde prospektif parsiyel nefrektomi uygulanması ile operasyonda onkolojik sonuçların iyileştirilmesi ve komplikasyonların azaltılması hedeflenmiştir. MP23-09, MP22-02, MP22-03, MP22-04, V9-10.

Yazışma Adresi:

Vahit Güzelburç

Medipol Üniversitesi, Tıp Fakültesi,

Üroloji Anabilim Dal, İstanbul

Tel: +90 5322856674

e-mail:akpinarlevent@hotmail.com 